\title{
An annotated checklist and bibliography of the Diaptomidae (Copepoda, Calanoida) of Italy, Corsica, and the Maltese islands
}

\author{
Giuseppe Alfonso, ${ }^{1}$ Fabio Stoch, ${ }^{2}$ Federico Marrone ${ }^{3 *}$ \\ ${ }^{1}$ Strada Comunale Paduligne 10, 73040 Specchia (LE), Italy; ${ }^{2}$ Evolutionary Biology and Ecology, Université libre de Bruxelles \\ (ULB), Avenue F.D. Roosevelt 50, 1050 Brussels, Belgium; ${ }^{3}$ Department of Biological, Chemical, and Pharmaceutical Sciences and \\ Technologies, University of Palermo, via Archirafi 18, 90123 Palermo, Italy
}

\begin{abstract}
Calanoids of the family Diaptomidae are the most widespread copepods in the lentic inland waters of the Palearctic region. In Italy, studies on the family date back to the end of $19^{\text {th }}$ century. Since then, several papers contributed to increase the knowledge on their presence, distribution, and ecological preferences. Nevertheless, new records for the area and the discovery of putative new species stress that the current knowledge on these inland water crustaceans is still far from being exhaustive. This paper presents an updated and annotated checklist and bibliography of the Diaptomidae of the Italian peninsula and surrounding islands, including Corsica and the Maltese islands, compiled through a critical review of the existing literature and carrying out further field research. The doubtful records reported in the literature are discussed and clarified. The updated checklist includes 30 diaptomid species and subspecies; among them, an alien species and three putative new species pending formal description are reported. About $20 \%$ of the observed species are endemic or subendemic to the study area. The faunal provinces ascribed to the Mediterranean limnofaunistic region host the highest species richness and contribute to the checklist with rare species and unique occurrences. The high species richness observed in the Mediterranean area supports the hypothesis of a long-lasting persistence of an ancient and peculiar copepod fauna.
\end{abstract}

\section{INTRODUCTION}

Calanoid copepods make up one of the major groups among inland water microcrustaceans and play an essential role in the trophic webs of lentic ecosystems, being thus a taxon of primary interest for both biogeographers and ecologists (Dussart and Defaye, 2001; Boxshall and Defaye, 2008). The strictly inland water family Diaptomidae largely dominates the water bodies of the Palearctic biogeographical region, being represented by 144 species (Boxshall and Defaye, 2008), 94 of which are reported from the western Palearctic (Błędzki and Rybak, 2016; Marrone et al., 2017). In this area, Marrone et al. (2017) described a complex scenario of post-glacial recolonization of the northern latitudes and highlighted the outstanding diversity of the family in the central and eastern Mediterranean countries comprised between $40^{\circ}$ and $45^{\circ}$

Corresponding author: federico.marrone@unipa.it

Keywords: Copepod diversity, inland waters, biogeography, Mediterranean region.

Received: 7 April 2021.

Accepted: 15 May 2021.

This work is licensed under a Creative Commons Attribution NonCommercial 4.0 License (CC BY-NC 4.0).

${ }^{\circ}$ Copyright: the Author(s), 2021

Licensee PAGEPress, Italy

J. Limnol., 2021; 80(3):2019

DOI: 10.4081/jlimnol.2021.2019
$\mathrm{N}$, from Italy to the Balkan peninsula and Asia Minor, although the limited number of recent synoptic works available for these areas was underlined as well.

The first comprehensive data on Italian Diaptomidae were compiled by Stella $(1979 a, 1982,1984)$ who reported 20 species for the country, brought later to 21 with the inclusion of the stygobitic Troglodiaptomus sketi Petkovski, 1978 (Stoch, 1984; Stella, 1995). Later, Stoch (2006a) reported the occurrence of 26 diaptomid taxa (belonging to 25 species) for Italy. Marrone et al. (2017) listed 26 autochthonous diaptomid species (subspecies were not considered) for mainland Italy, Corsica, Malta, and the Italian side of the Alps. Belmonte (2018) reported 27 species for the whole Italian fauna, including the non-native Eudiaptomus gracilis (Sars, 1863). However, due to the inherent synoptic nature of this last paper, the presence of some taxa was overlooked or was not critically discussed, and a complete repository of the bibliographical sources dealing with the family Diaptomidae in the study area was not provided.

Although the Diaptomidae is admittedly the dominant calanoid family occurring in the Holarctic inland waters (Dussart and Defaye, 2002), other families are represented in the study area. Temoridae, with the occurrence of Heterocope saliens (Lilljeborg, 1862) (Stoch, 2006a), Pseudodiaptomidae, with Calanipeda aquaedulcis Kritschagin, 1873 (Stoch, 2006a, Vecchioni et al., 2019), and Centropagidae, with the non-native Boeckella triarticulata (Thomson, 1883) (Ferrari and Rossetti, 2006; Alfonso and Belmonte, 2008), occur in the inland waters of the study area, whereas representatives of the families Acartiidae and Pseudodiaptomidae can be found in coastal ponds and lagoons, with brackish and marine waters (Belmonte, 2018). 
The aims of the present paper are (i) to compile an updated checklist of Diaptomidae in Italy, Corsica, and the Maltese islands based on a critical review of recent literature and unpublished data, (ii) to assemble an exhaustive repository of the literature dealing with the diaptomids of the study area between 2000 and 2020, and (iii) to carry out a biogeographical analysis of the diaptomids occurring in the study area, with a focus on the affinities existing with neighbouring west-Palearctic limnofaunistic regions sensu Illies (1967).

\section{METHODS}

\section{Study area}

The geographical area covered by the present paper includes the limnofaunistic region "ITA" as defined by Illies (1967), i.e., mainland Italy, Sicily, Sardinia, Maltese islands, and Corsica, with the addition of the Italian slope of the Alps. The study area is then divided in the zoogeo- graphical provinces defined by Minelli et al. (2006) as modified by Stoch (2006b), along with some islands which administratively belong to different countries but are geographically and geologically part of the study area, i.e., Corsica and the Maltese islands (Fig. 1). A minor modification to the above-mentioned provinces was made by the authors to the Tyrrhenian province, adding to it some coastal plains in Campania and Calabria which share climatic and geomorphological features with this province (Fig. 1). All the zoogeographical provinces were then grouped in five macroareas based on their climatic, geographic, and physiographic features (Tab. 1). The shapefile of the mentioned provinces is provided as supplementary material available online (File S1).

\section{Bibliographical review and nomenclature}

An exhaustive database of the papers citing the presence of diaptomids up to December 2020 was compiled for the whole study area based on the datasets of the authors,

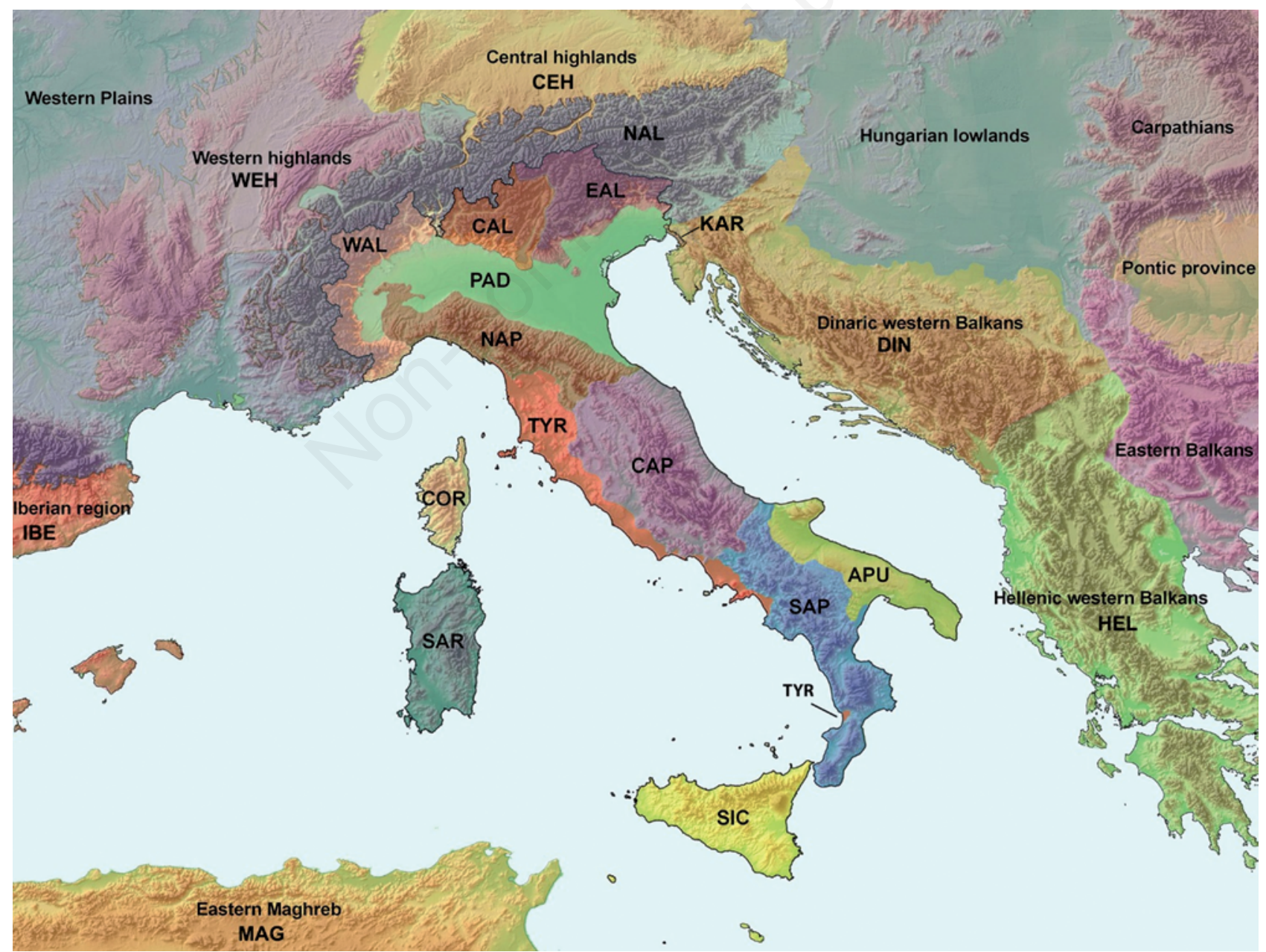

Fig. 1. The Italian zoogeographical provinces and neighbouring limnofaunistic regions (see text for details). 
including 'grey literature', plus an extensive literature search through the databases of SCOPUS (www.scopus. com) and Google Scholar (https://scholar. google.it/). As regards the occurrence data pertaining to the politically Italian part of the study area, the bibliography included in the electronic material associated to the paper by Stoch (2006a) was considered exhaustive and reliable for all the papers published before 2000. Conversely, the whole literature dealing with the diaptomids of Corsica and the Maltese islands was carefully reviewed.

All obtained occurrence data were critically revised and, when possible, checked through dedicated sampling surveys. Particular attention was paid to the check of the occurrence data reported by strictly ecological papers where the accurate identification of copepods was not the primary aim of the work, since identifications might have been carried out by non-specialists of the taxon.

Diaptomid nomenclature used herein is largely based on Dussart and Defaye (2002), with the only exception of taxa described or changed in rank after that publication (see Marrone et al., 2017 for details).

In the updated and annotated checklist presented here, the scientific name of each taxon is followed by the acronyms of the provinces where it is known to occur (Fig. 1; Tab. 1). When the presence of a taxon in a given province was considered doubtful or marginal, the acronym of the province is reported among round or square brackets, respectively, and the case is discussed in detail. Marginal occurrences are those represented by a single or few records occurring at the boundary of the species range and usually in atypical environments, which were confirmed by at least two authors andlor by specimens preserved in collections. Occurrences which do not fall under the previous conditions or were not confirmed by subsequent research in the same or neighbouring sites are considered doubtful.

All the references mentioning the presence of diaptomid species and subspecies in the study area are also reported, from 2000 up to December 2020 (for the Italian references), or from 1894 to December 2020 for the references pertaining to Corsica (France) and the Maltese islands (Malta).

\section{Data analysis}

The affinities among the diaptomid faunas of the zoogeographical provinces reviewed here and the neighboring limnofaunistic regions described in Marrone et al. (2017) were investigated. The occurrence data about Diaptomidae occurring in the regions surrounding the study area were retrieved from Marrone et al. (2017) with some changes: i) since in the frame of the present work the subspecies are explicitly treated, the taxon reported as Eudiaptomus padanus (Burckhardt, 1900) for "Dinaric western Balkans" (DIN) by Marrone et al. (2017) is here reported as Eudiaptomus padanus etruscus (Losito, 1901); ii) a new limnofaunistic unit was added, coded NAL ("Northern Alps"), to include the "Alpine region" (ALP) of Marrone et al. (2017) excluding the Italian part of the Alps; iii) the Italian province KAR (i.e., the part of the DIN region included within the Italian administrative borders) was included in DIN;(iv) the taxa Hemidiaptomus cf. inermis Kiefer, 1954 and Eudiaptomus sp. EMILIA-ROMAGNA, which were not listed by Marrone et al. (2017) are here included in the analyses (see text).

The occurrences of Diaptomus cyaneus Gurney, 1909 in TYR, Hemidiaptomus gurneyi (Roy, 1927) in SAR, Eudiaptomus zachariasi (Poppe, 1886) in KAR,

Tab. 1. List of the zoogeographical provinces of the study area, their acronyms, macroareas, area (in $\mathrm{km}^{2}$ ) and diaptomid species richness.

\begin{tabular}{|c|c|c|c|c|}
\hline Macroarea & Province & Acronym & Area $(\mathrm{km} 2)$ & Species \\
\hline Alpine & Central Alps & CAL & 15,618 & 7 \\
\hline Alpine & Eastern Alps & EAL & 20,290 & 5 \\
\hline Alpine & Western Alps & WAL & 17,488 & 5 \\
\hline Apennine & Central Apennines & CAP & 48,475 & 9 \\
\hline Apennine & Northern Apennines & NAP & 28,035 & 3 \\
\hline Apennine & Southern Apennines & SAP & 36,724 & 5 \\
\hline Balkan & Karst plateau & KAR & 268 & 2 \\
\hline Mediterranean & Apulia & APU & 18,829 & 13 \\
\hline Mediterranean & Corsica & $\mathrm{COR}$ & 8731 & 6 \\
\hline Mediterranean & Sardinia & SAR & 24,104 & 8 \\
\hline Mediterranean & Sicily and Malta & SIC & 26,028 & 11 \\
\hline Mediterranean & Tyrrhenian area & TYR & 19,855 & 4 \\
\hline Padanian & Padanian plain & PAD & 46,031 & 6 \\
\hline
\end{tabular}


Eudiaptomus intermedius (Steuer, 1897) in WAL, and Arctodiaptomus wierzejskii (Richard, 1888) in WAL were not included in the occurrence matrix analyzed since their actual occurrence is doubtful in the mentioned areas (see below). Likewise, the analyzed occurrence matrix did not include Mixodiaptomus kupelwieseri (Brehm, 1907) in WAL and Arctodiaptomus alpinus (Imhoff, 1885) in NAP because the species have been considered marginal presences there. Moreover, the occurrence of Eudiaptomus gracilis in the Italian provinces was not included in the matrix since the species is currently considered non-native in the whole study area (Marrone et al., 2017). The resulting matrix included 55 species and subspecies of Diaptomidae and 19 biogeographical units (13 of which are the Italian zoogeographical provinces described above: File S2).

The similarities among the diaptomid faunas were analysed using non-metric Multi-Dimensional Scaling (nMDS). The resemblance matrix of the occurrence data was based on the Jaccard index. The Spearman's correlation coefficient was used to identify the species that mostly contributed to the characterisation of each biogeographical unit. Species which were not significant $(p>0.05)$ were not considered further. Analyses were performed using the software PRIMER-E v.6.1.11 (Clarke and Gorley, 2006), including the PERMANOVA+ v.1.0.1 add-on package (Anderson et al., 2008).

\section{RESULTS}

Overall, 29 diaptomid species and 1 subspecies, three of them still pending a formal description, were recorded in the study area (Tab. 2). In addition to the species listed below, Kiefer (1978) and Dussart and Defaye (2002) reported the presence of Arctodiaptomus similis (Baird, 1859) in Sardinia, although no other data were provided by these authors to substantiate the record of this species, which occurs in eastern Europe and the Middle East (Marrone et al., 2014). A review of the correspondence between late prof. E. Stella and prof. F. Kiefer (now deposited in F. Stoch library) led to the finding of an explicit mention of a single female Arctodiaptomus specimen from Sardinia whose morphology and chaetotaxy were compatible with $A$. similis (File S3). An effort spent in March 2018 aimed at collecting the species in Sardinia was unfruitful (F. Marrone and F. Stoch, pers. obs.). Pending further evidence, its occurrence in a Sardinian sample (a single female was found, and no further specimens were obtained from the samples re-examined by E. Stella upon Kiefer's request, as written in the letter: File S3) is here tentatively ascribed to the mislabelling or "contamination" of the studied sample, and A. similis is thus excluded from the Sardinian and Italian fauna.

\section{Annotated checklist}

\section{Subfamily DIAPTOMINAE Kiefer, 1932}

Acanthodiaptomus denticornis (Wierzejski, 1887). WAL, CAL, EAL. In the study area, this species is limited to the Alpine mountain range (Stoch, 2006a). Other references: Jersabek et al., 2001; Angeli et al., 2002; Tolotti et al., 2006; Bruno et al., 2010; Marrone et al., 2017; Belmonte, 2018.

Arctodiaptomus (Arctodiaptomus) kerkyrensis (Pesta, 1935). SAP, APU, SIC. This species has a distribution limited to the southern part of the Italian peninsula and Sicily. The first record in the study area was reported by Licchelli et al. (2003) for the Southern Apennines. Later, other point records followed in Sicily (Marrone et al., 2006a) and Apulia (G. Alfonso, F. Marrone and F. Stoch, unpubl. data). Other references: Belmonte et al., 2006; Marrone, 2006; Marrone et al., 2006b, 2009, 2019; Belmonte, 2018.

Arctodiaptomus (Arctodiaptomus) sp. SICILY. SIC. Following Stella (1984, and references therein), NaselliFlores and Barone (2002), Marrone and Naselli-Flores (2004), Stoch (2006a), Marrone (2006), and Marrone et al. (2006a, 2006b) reported the occurrence of Arctodiaptomus stephanidesi (Pesta, 1935) in Sicily, also reported as "Arctodiaptomus stefanidesi" (sic!) in Belmonte (2018). In fact, the Sicilian populations ascribed to this taxon belong to a putative new species, currently pending a formal description (Marrone et al., 2009; 2017). Other references: Marrone et al., 2013, 2014, 2019.

Arctodiaptomus (Arctodiaptomus) wierzejskii (Richard, 1888). (WAL), CAP, APU, SAR, COR, SIC. This widespread Palearctic species is present in Corsica (Schachter and Champeau, 1969), Sardinia (Stoch, 2006a), Apulia (Alfonso and Belmonte, 2011; Alfonso et al., 2016) and in a single high-altitude site in the central Apennine area (Stoch, 2006a). Moreover, it is present in Malta (Marrone et al., 2009; Montevago et al., 2020), although the species seems to be absent from mainland Sicily (F. Marrone, 2006a, and pers. obs.). Its occurrence in Lake Orta, north-western Italy (Bonacina and Pasteris, 2001) was temporary, following a period of high pollution, and the species is no more part of the zooplankton community of the lake (Piscia et al., 2016). Other references: Champeau, 1971; Champeau and Thiéry, 1990; Lanfranco and Cassar, 2003; Scirocco et al., 2008; Alfonso and Belmonte, 2013; Marrone et al., 2013, 2017; Belmonte, 2018.

Arctodiaptomus (Rhabdodiaptomus) alpinus (Imhoff, 1885). WAL, CAL, EAL, [NAP]. A widely distributed species throughout the Palearctic region (Dussart and Defaye, 2002) including the Mediterranean island of Crete (Marrone et al., 2019). Some doubts on the con- 
specificity of the Mongolian and European populations were raised by Marrone et al. (2015). In the study area, it occurs on the whole Alpine mountain range, both in permanent and temporary water bodies (Jersabek et al., 2001; Stoch, 2006a). Its only record in NAP is the lake Giacopiane (Giussani et al., 1986). Other references: Jersabek et al., 2001; Angeli et al., 2002; Manca and Armiraglio, 2002; Marchetto et al., 2004; Tolotti et al., 2006; Tiberti, 2011; Tiberti and Barbieri, 2011; Iacobuzio and Tiberti, 2011; Magnea et al., 2013; Tiberti and Iacobuzio, 2013; Tiberti et al., 2013, 2014a, 2014b, 2016, 2019, 2020a, 2020b; Marrone et al., 2014, 2017; Belmonte, 2018.
Arctodiaptomus (Rhabdodiaptomus) salinus (Daday, 1885). APU, SIC, SAR. A halophilous species currently reported only for Sardinia (Stoch, 2006a), Sicily (Marrone et al., 2006a) and a single coastal wetland in Apulia (Alfonso and Belmonte, 2011). Other references: Marrone, 2006; Marrone et al., 2006b, 2009, 2013, 2017; Alfonso et al., 2010; Anufriieva and Shadrin, 2015; Belmonte, 2018.

Copidodiaptomus numidicus (Gurney, 1909). SIC, SAR, COR. A western Mediterranean species, absent in the Italian peninsula but rather common in Corsica (Schachter and Champeau, 1969), Sardinia (Stoch, 2006a; Fadda et al., 2011), and Sicily (Stoch, 2006a;

Tab. 2. Checklist of the Italian Diaptomidae and their occurrence in the Italian zoogeographical provinces.

\begin{tabular}{|c|c|c|c|c|c|c|c|c|c|c|c|c|c|}
\hline \multirow[b]{2}{*}{ Taxa } & \multicolumn{11}{|c|}{ AlpineBalkanPadanianaApennineMediterranean } & \multirow{2}{*}{\multicolumn{2}{|c|}{ SAR COR }} \\
\hline & Acronym & WAL & CAL & EAL KA & PAD & NAP & CAP & SAP & TYR & APU & SIC & & \\
\hline \multicolumn{14}{|l|}{ Diaptominae } \\
\hline Acanthodiaptomus denticornis (Wierzejski, 1887) & Acaden & 1 & 1 & 1 & & & & & & & & & \\
\hline Arctodiaptomus (Arctodiaptomus) kerkyrensis (Pesta, 1935) & Arcker & & & 20 & & & & 1 & & 1 & 1 & & \\
\hline Arctodiaptomus (Arctodiaptomus) sp. SICILY & Arcsp & & & 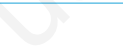 & & & & & & & 1 & & \\
\hline Arctodiaptomus (Arctodiaptomus) wierzejskii (Richard, 1888) & Arcwie & $(1)$ & & & & & 1 & & & 1 & 1 & 1 & 1 \\
\hline Arctodiaptomus (Rhabdodiaptomus) alpinus (Imhoff, 1885) & Arcalp & 1 & 1 & 1 & & {$[1]$} & & & & & & & \\
\hline Arctodiaptomus (Rhabdodiaptomus) salinus (Daday, 1885) & Arcsal & & & & & & & & & 1 & 1 & 1 & \\
\hline Copidodiaptomus numidicus (Gurney, 1909) & Copnum & & & & & & & & & & 1 & 1 & 1 \\
\hline Copidodiaptomus steueri (Brehm, 1904) & Copste & & 1 & 1 & & & 1 & 1 & & 1 & & & \\
\hline Diaptomus (Chaetodiaptomus) cyaneus Gurney, 1909 & Diacya & 1 & & & & & 1 & & (1) & 1 & 1 & 1 & 1 \\
\hline Diaptomus (Chaetodiaptomus) serbicus Gjorgjewič, 1907 & Diaser & & & & & & & & 1 & 1 & 1 & & \\
\hline Eudiaptomus gracilis (Sars, 1863) & Eudgra & $1^{*}$ & $1 *$ & & $1 *$ & & $1 *$ & & & & & & \\
\hline Eudiaptomus intermedius (Steuer, 1897) & Eudint & $(1)$ & 1 & 1 & 1 & 1 & 1 & & & & & & \\
\hline Eudiaptomus padanus etruscus (Losito, 1901) & Eudetr & & & & 1 & & 1 & & 1 & 1 & & & \\
\hline Eudiaptomus padanus padanus (Burckhardt, 1900) & Eudpad & 1 & 1 & & 1 & & & & & & & & \\
\hline Eudiaptomus sp. EMILIA-ROMAGNA & Eudsp & & & & 1 & & & & & & & & \\
\hline Eudiaptomus vulgaris (Schmeil, 1898) & Eudvul & & 1 & & & & 1 & 1 & & & & & \\
\hline Eudiaptomus zachariasi (Poppe, 1886) & Eudzac & & & (1) & & & 1 & & & & & & \\
\hline Hemidiaptomus (Gigantodiaptomus) superbus (Schmeil, 1895) & Hemsup & & & & 1 & & & & & & & & \\
\hline Hemidiaptomus (Hemidiaptomus) gurneyi (Roy, 1927) & Hemgur & & & & & & & & 1 & 1 & 1 & $(1)$ & \\
\hline Hemidiaptomus (Occidodiaptomus) cf. inermis Kiefer, 1954 & Hemine & & & & & & & & & 1 & & & 1 \\
\hline Hemidiaptomus (Occidodiaptomus) ingens (Gurney, 1909) & Heming & & & & & & & & & & 1 & & \\
\hline Hemidiaptomus (Occidodiaptomus) roubaui (Richard, 1888) & Hemrou & & & & & & & & & & & 1 & \\
\hline Mixodiaptomus kupelwieseri (Brehm, 1907) & Mixkup & [1] & & & 1 & 1 & 1 & 1 & 1 & 1 & 1 & 1 & 1 \\
\hline Mixodiaptomus incrassatus (Sars, 1903) & Mixinc & & & & & & & & & 1 & & 1 & \\
\hline Mixodiaptomus laciniatus laciniatus (Lilljeborg, 1889) & Mixlac & 1 & 1 & & & & & & & & & & 1 \\
\hline Mixodiaptomus lilljeborgi (Guerne and Richard, 1888) & Mixlil & & & & & & 1 & 1 & & 1 & & 1 & \\
\hline Mixodiaptomus tatricus (Wierzejski, 1883) & Mixtat & & 1 & 1 & & 1 & & & & & & & \\
\hline \multicolumn{14}{|l|}{ Paradiaptominae } \\
\hline Metadiaptomus chevreuxi (Guerne and Richard, 1894) & Metche & & & & & & & & & & 1 & & \\
\hline Neolovenula alluaudi (Guerne and Richard, 1890) & Neoall & & & & & & & & & 1 & & & \\
\hline \multicolumn{14}{|l|}{ Speodiaptominae } \\
\hline Troglodiaptomus sketi Petkovski, 1978 & Troske & & & 1 & & & & & & & & & \\
\hline
\end{tabular}

*non-indigenous occurrence; (1): doubtful record; [1]: marginal occurrence. 
Marrone et al., 2006a). Other references: Champeau, 1971; Champeau and Thiéry, 1990; Marrone, 2006; Marrone et al., 2006b, 2009, 2013, 2017; Alfonso et al., 2010; Fadda et al., 2014, 2016; Troia et al., 2016; Belmonte, 2018; Naselli-Flores and Marrone, 2019; Vecchioni et al., 2019, 2020.

Copidodiaptomus steueri (Brehm, 1904). CAL, EAL, CAP, SAP, APU. The species occurs in the Adriatic hydrographic basins of Italian peninsula and northern Balkans (Stoch, 2006a; Ternjej and Stanković, 2007; Alfonso et al., 2010; Alfonso and Belmonte, 2011). The report of the species for an artificial lake in southern Sardinia (Cioglia et al., 1969) is erroneous and due to a misidentification of the closely related C. numidicus as confirmed by recent samples collected from the lake (F. Marrone and F. Stoch, pers. obs). Other references: Garibaldi et al., 2003; Bettinetti et al., 2012; Leoni, 2017; Marrone et al., 2017; Belmonte, 2018.

Diaptomus (Chaetodiaptomus) cyaneus Gurney, 1909. WAL, CAP, (TYR), APU, SIC, SAR, COR. This species is rather common in the temporary ponds of Corsica (Schachter and Champeau, 1969), Sardinia (Stoch, 2006a), Sicily (Marrone et al. 2006a) and Apulia (Alfonso and Belmonte, 2011; Alfonso et al. 2016). Moreover, high-altitude populations of the species are reported for temporary water bodies in the Central Apennine area (Stoch, 2006a), and for permanent lakes in Corsica (Pesta, 1938) and on the western Alps, where the species occurs both on the French (Pirocchi, 1947; Dussart, 1957) and Italian slopes (Marrone and Stoch, unpublished data). The occurrence of the species in the ponds of the Nature Reserve "Oasi di Palo", near Rome (Mura and Brecciaroli, 2003) is doubtful and may actually refer to D. serbicus (Brecciaroli, in litteris). Moreover, the Apulian sites reported for the species by Scirocco et al. (2008) must in fact be referred to Diaptomus serbicus (Alfonso and Belmonte, 2011). Diaptomus castor Jurine, 1820 reported for Ile Rousse (Corsica) by Richard (1894$1895)$ is here ascribed to a misidentification of $D$. cyaneus since $D$. castor does not occur in the Mediterranean area (Kiefer, 1978), and the record was published before the description of D. cyaneus (Gurney, 1909). Other references: Champeau, 1971; Champeau and Thiéry, 1990; Marrone and Naselli-Flores, 2004; Marrone 2006; Marrone et al. 2006b, 2009, 2013, 2017; Alfonso and Belmonte, 2013; Troia et al., 2016; Belmonte, 2018; dos Santos-Silva et al., 2018.

Diaptomus (Chaetodiaptomus) serbicus Gjorgjewič, 1907. TYR, APU, SIC. D. serbicus is the westernmost species of the mirus group within the genus Diaptomus (Kiefer, 1972). In the study area, the species is so far only reported for temporary ponds in Latium (e.g., Stoch 2006a), Sicily (Marrone et al., 2006a), and Apulia (Alfonso and Belmonte, 2011). Other references: Vagaggini et al., 2002; Marrone, 2006; Marrone et al., 2006b, 2009, 2010, 2013, 2017, 2019; Seminara et al., 2015, 2016; Belmonte, 2018; dos Santos-Silva et al., 2018.

Eudiaptomus gracilis (Sars, 1863). WAL, CAL, PAD, CAP. According to Riccardi and Rossetti (2007) and Marrone et al. (2017) Eudiaptomus gracilis is to be considered an alien species in Italy, although its status was never tested through a thorough analysis. The older citations for this species in Italy are due to misidentifications and must be referred to other species (Kiefer, 1968; Stoch, 2006a), and the first certain record dates back to the early 1980s (de Bernardi et al., 1984). E. gracilis is currently widespread in northern and central Italy (F. Stoch., unpublished data), possibly threatening native diaptomid species (e.g., Riccardi and Giussani, 2007; Visconti and Manca, 2010). Other references: Viaroli et al., 2002; Rossetti et al., 2003a, 2003b; Margaritora et al., 2006; Gherardi et al., 2008; Fontanella et al., 2009; Rossetti et al., 2009; Tavernini et al., 2009b; Visconti and Manca, 2011; Riccardi et al., 2012; Belmonte, 2018; Lepori et al., 2018; Piscia et al. 2018; Visconti et al. 2018; Lepori, 2020; Lepori and Capelli, 2020; Setubal et al., 2020; Tanentzap et al., 2020.

Eudiaptomus intermedius (Steuer, 1897). (WAL), CAL, KAR, PAD, NAP, CAP. Stoch (2006a) reports several occurrence localities of the species in central and northern peninsular Italy, whereas its occurrence in the Western Alps remains doubtful. The species was reported from a lake in the Lys Valley (Aosta) by Brian (1927); however, recent surveys in the area (F. Stoch, pers. obs.) failed to confirm its presence. Marrone et al. (2011b) and Galassi et al. (2017) reported the occurrence of a stygomorphic population of the species for the Frasassi cave system, in The Marches. Other references: Moroni and Bellavere, 2001; Tavernini and Rossetti, 2001; Rossetti et al., 2002, 2004; Tavernini et al., 2003; Rossetti, 2005; Bondavalli et al., 2006; Rossetti et al., 2006; Tavernini et al., 2009a; Riccardi et al., 2012; Ferrari et al., 2014; Marrone et al., 2017; Belmonte, 2018; Rogora et al., 2018.

Eudiaptomus padanus etruscus (Losito, 1901). PAD, CAP, TYR, APU. This taxon was described by Losito (1901, erroneously reported with the date 1911 in Stella, 1984) as Diaptomus etruscus from Bracciano Lake, Latium. In his revision of the genus Eudiaptomus, Kiefer (1968) reported E. padanus etruscus for several lakes and ponds in central Italy, while describing 'E. padanus etruscus forma sexsetosa (nov.)' from lakes Bracciano, Bolsena and Albano based on the presence of six setae on the third segment of endopods of P2-P4 instead of seven as reported by Losito. Being 
the name 'sexsetosa' not available due to the year of description (after 1960: ICZN, art. 45.6), Kiefer (1978) redescribed it as 'Eudiaptomus padanus etruscosexsetosus n. subsp.'; in this way two different subspecies of the same species resulted present in the type locality of E. padanus etruscus, i.e. Lake Bracciano. For some reason Kiefer was not aware of this fact, and the same nomenclature was adopted in the field guide by Stella (1982). Finally, Stella (1984) pointed out the variability of the number of setae in the lakes of central Italy, and attributed all the material of ponds and lakes of Central Italy to Eudiaptomus padanus etruscus; accordingly, we consider E. padanus etruscosexsetosus as a junior synonym of $E$. padanus etruscus, an opinion suggested also by Stoch (2006a). E. padanus etruscus, which occurs also along the Croatian Adriatic coastal area (Ternjej and Stanković, 2007), is widely distributed in ponds and lakes of central and southern Italy as well as in ponds of the eastern Padanian plain (Stoch, 2006a and references reported below). The species is present also in Apulia, where it was erroneously reported (see below) as E. vulgaris by Alfonso and Belmonte (2011) and Belmonte (2018). Other references: Margaritora et al., 2001, 2003; Ferrara et al., 2002; Vagaggini et al., 2002; Riccardi and Rossetti, 2007; Riccardi et al., 2012; Seminara et al., 2008, 2015, 2016; Marrone et al., 2017; Belmonte, 2018.

Eudiaptomus padanus padanus (Burckhardt, 1900). WAL, CAL, PAD. Eudiaptomus padanus was described from Lake Maggiore by Burckhardt (1900) as 'Diaptomus graciloides Lillj. var. nov. padana'; in a further paper (Burckhardt, 1914) it was considered as a good species, Diaptomus padanus. For this reason, following ICZN rules (art. 45.6) the name 'padanus' is valid and attributed to Burckhardt (1900). The species is widely distributed in the larger Italian subalpine lakes as well as in smaller, permanent basins and rivers (Diaptomus larianus Baldi, 1925 from Como Lake and Eudiaptomus vulgaris sicidae Pirocchi, 1940 are junior synonyms of this species). Other references: Manca et al., 2000, 2004; Cotta-Ramusino and Leoni, 2001; Viaroli et al., 2002; Rossetti et al., 2003a; Stoch, 2006a; Riccardi and Giussani, 2007; Riccardi and Rossetti, 2007; Rossetti et al., 2009; Stefani et al., 2010; Visconti et al., 2010, 2011, 2018; Riccardi et al., 2012; Piscia et al., 2016, 2018; Morabito, 2017; Marrone et al., 2017; Belmonte, 2018; Lepori, 2020; Tanentzap et al., 2020.

Eudiaptomus sp. EMILIA-ROMAGNA. PAD. Tavernini et al. (2009b) reported the presence of a putative new Eudiaptomus species in two sand-pit lakes in Emilia Romagna. A recent re-examination of this material and further surveys (G. Alfonso, F. Marrone and F. Stoch, pers. obs.) confirm this supposition, and this taxon is currently pending a formal description. Other references: none.

Eudiaptomus vulgaris (Schmeil, 1898). CAL, CAP, SAP. The species is reported for a few localities on the central (Stella, 1984; Stoch, 2006a; Osella and Pannunzio, 2013) and southern Apennines (Stella, 1979b; Alfonso et al., 2010), and it was cited in a single occasion for rock pools on the Karst Plateau near Trieste (Pirocchi, 1942; Ranzoli et al., 1979). However, the presence of the species on the Karst Plateau is probably erroneous (Stoch, 2006a): after over twenty years of intensive sampling performed in the period 1984-2005 in the same rock-pools and in neighbouring ponds and pools, no diaptomids were found in rock-pools environments, while E. intermedius only was collected in ponds and pools of KAR area (Stoch, 2006a; F. Stoch, unpubl. data). For this reason, and considering that the specimens were not found in Stella collection (University of Rome: F. Stoch, pers. obs.), the species is considered absent in KAR, and its citations in Karst rock pools probably due to mislabelling. Moreover, the diaptomid reported in Apulia as E. vulgaris by Alfonso and Belmonte (2011) and Belmonte (2018) is in fact Eudiaptomus padanus etruscus (G. Alfonso, pers. $o b s$.). The species was recently collected in a pond in South Tyrol (CAL) by F. Stoch (unpubl. data). Finally, Stella (1957) reported E. vulgaris for a lake ("Lago Abissale") inside the cave of "Bue Marino", in Sardinia. The re-examination of the samples in Stella crustacean collection by one of us (F. Stoch) allowed to assess that this sample was in fact intermixed with pond fauna coming from the Italian peninsula, so that an exchange of labels is the most probable explanation of this erroneous record. The "Lago Abissale" is in fact mainly a sea arm entering the coastal cave and thus completely unsuitable for the presence of this diaptomid species (F. Stoch, pers. obs.); accordingly, Casale et al. (2008) excluded it from the checklist of that cave, and consequently from SAR. Other references: Stella, 1984; Marrone et al., 2013, 2017.

Eudiaptomus zachariasi (Poppe, 1886). CAP, (KAR). This species was first reported by Tonolli (1959) for the "Pantani di Forca Canapine", in the central Apennine Mountains (CAP), where in 2010 E. zachariasi was still present with a thriving population (G. Alfonso, F. Marrone and F. Stoch, pers. obs.). Conversely, the occurrence of the species in artificial ponds in the garden of the castle of Miramare (Trieste, north-eastern Italy: Langhans, 1907, Tonolli, 1959, Stella, 1984) was not confirmed by recent surveys and the local extinction of the species could be possibly related to the introduction of fish in those ponds (G. Alfonso and F. Stoch, pers. obs.). Since occurrence 
sites in north-eastern Italy were limited to man-made water bodies, its autochthony in this area is doubtful. Other references: Stoch, 2006a; Marrone et al., 2017.

Hemidiaptomus (Gigantodiaptomus) superbus (Schmeil, 1895). PAD. H. superbus, currently unanimously considered one of the rarest Palearctic diaptomid species (Dussart, 1967; Kiefer, 1978; Einsle, 1993), was recently found in the Padanian province (Marrone et al., 2011a). This is the only record of a representative of the subgenus Gigantodiaptomus south of the Alps. According to Einsle (1993) the species should be ascribed to the subgenus Hemidiaptomus s. str. This proposal is also supported by a cladistic analysis of the genus Hemidiaptomus based on morphological characters (Marrone et al., 2013). However, to date no exhaustive molecular evidence is available to support this option, so that it is here conservatively maintained within the subgenus Gigantodiaptomus in accordance with Dussart and Defaye (2002). Other references: Marrone et al., 2017; Belmonte, 2018.

Hemidiaptomus (Hemidiaptomus) gurneyi (Roy, 1927). TYR, APU, SIC, (SAR). The commonest and most widespread Hemidiaptomus species in Italy, H. gurneyi inhabits temporary ponds and pools of the coastal areas of Tuscany (Marrone et al., 2010), Latium (Stoch, 2006a), Calabria (Marrone et al., 2013) and Apulia, where it is also present in ponds of the Gargano promontory over $600 \mathrm{~m}$ asl (Alfonso and Belmonte, 2011). It is also reported for medium to high-altitude temporary water bodies in Sicily (Marrone et al., 2006a, 2006b). The record of the species for a single site in Sardinia (Margraf and Maas, 1982) lies out of the distribution range of the species and could not be confirmed in spite of extensive samplings carried out by the authors with the explicit aim of checking its presence, and hence it is likely erroneous. Other references: Vagaggini et al., 2002; Mura and Brecciaroli, 2003; Marrone, 2006; Marrone et al., 2009; 2016, 2017; Scirocco et al., 2008; Seminara et al., 2015, 2016; Belmonte, 2018.

Hemidiaptomus (Occidodiaptomus) cf. inermis Kiefer, 1954. APU, COR. According to Marrone et al. (2013), the Corsican populations of the species reported as Hemidiaptomus ingens inermis by Schachter and Champeau (1969) and the Apulian populations of the species reported as Hemidiaptomus ingens by Alfonso and Belmonte (2011) and Alfonso et al. (2016) should rather be ascribed to a different species, which is morphologically very similar to Hemidiaptomus inermis. However, in the light of the pronounced morphological conservatism of Diaptomidae, a molecular comparison with the topotypical population of $H$. inermis s.str. (La Reghaïa, Algeria; Kiefer, 1954) should be carried out to check their conspecificity. Pending such a revision, we report this species here as Hemidiaptomus cf. inermis. Other references: Alfonso and Belmonte, 2013; Champeau, 1971; Champeau and Thiéry, 1990; Marrone et al., 2017.

Hemidiaptomus (Occidodiaptomus) ingens (Gurney, 1909). SIC. First recorded in Italy by Marrone and Naselli-Flores (2004). According to Marrone et al. (2013), H. ingens s. str. only occurs in Tunisia and Sicily, where it inhabits temporary ponds located at low altitude. The taxon indicated as $H$. ingens inermis in Corsica (Schachter and Champeau, 1969) and as $H$. ingens in Apulia (Alfonso and Belmonte, 2011; Alfonso et al., 2016) is rather to be ascribed to Hemidiaptomus cf. inermis (see above). Other references: Marrone, 2006; Marrone et al., 2006a, 2006b, 2009, 2010, 2017; Troia et al., 2016.

Hemidiaptomus (Occidodiaptomus) roubaui (Richard, 1888). SAR. Within the study area, this species is so far only known from Sardinia, where it occurs in temporary water bodies both in the central and northern parts of the island (Margraf and Maas, 1982; Stoch, 2006a; Boix et al., 2017). Other references: Bagella et al., 2010, 2011; Marrone et al., 2013, 2017; Belmonte, 2018.

Mixodiaptomus incrassatus (Sars, 1903). APU, SAR. The known distribution of the species in the study area only includes northern Sardinia (Stella 1984) and Apulia (Alfonso and Belmonte, 2011), where the species occurs in temporary ponds located in arid and semiarid areas, often co-occurring with other diaptomids. Other references: Alfonso and Belmonte, 2013; Alfonso et al., 2016; Marrone et al., 2017; Belmonte, 2018.

Mixodiaptomus kupelwieseri (Brehm, 1907). [WAL], PAD, NAP, CAP, SAP, TYR, APU, SIC, SAR, COR. It is the most widely distributed species in the study area, occurring throughout the Italian peninsula, Corsica, Sardinia, and Sicily (Stella, 1984; Schachter and Champeau, 1969; Stoch, 2006a; Marrone et al., 2006a; Alfonso and Belmonte, 2011). The occurrence in WAL, being related to a single pond located at 390 m a.s.1. (lake La Mula, near Novara) (Ravera, 1951), can be considered marginal. Other references: Champeau, 1971; Champeau and Thiéry, 1990; Moroni and Bellavere, 2001; Tavernini and Rossetti, 2001; Vagaggini et al., 2002; Mura and Brecciaroli, 2003; Tavernini et al., 2003; Rossetti et al., 2004; Marrone, 2006; Marrone et al., 2006b, 2009, 2011a, 2017; Tavernini, 2008; Tavernini et al., 2005, 2009a; Ferrari et al., 2014; Seminara et al., 2008, 2015, 2016; Troia et al., 2016; Belmonte, 2018.

Mixodiaptomus laciniatus laciniatus (Lilljeborg, 1889). WAL, CAL, COR. Until the middle of the 20th century, the nominotypical subspecies of Mixodiaptomus 
laciniatus was present in several large, subalpine lakes of the western and central Alps, from where it later disappeared possibly due to eutrophication and pollution, surviving only in Lake Maggiore (Stella, 1984; Stoch, 2006a). Visconti and Manca (2010) raised some concerns about its long-term survival due to the competition with the non-indigenous Eudiaptomus gracilis. However, the species luckily still survives in Lake Maggiore, although with a smaller population (Morabito, 2017; R. Piscia, pers. com.). The species is also present in a single pond in Corsica (Schachter and Champeau, 1969; F. Marrone and F. Stoch, pers. obs). Other references: Champeau, 1971; Champeau and Thiéry, 1990; Manca et al., 2004 ; Marrone et al., 2017; Belmonte, 2018; Lepori, 2020 ; Tanentzap et al., 2020.

Mixodiaptomus lilljeborgi (Guerne and Richard, 1888). CAP, SAP, APU, SAR. A widespread and euryecious species, currently known from Sardinia (Stoch, 2006a; Boix et al., 2017), northern Apulia (Alfonso and Belmonte, 2011), and Central and Southern Apennines (Stoch, 2006a). Other references: Belmonte et al., 2006; Alfonso et al., 2010; Bagella et al., 2010, 2011; Marrone et al., 2017; Belmonte, 2018.

Mixodiaptomus tatricus (Wierzejski, 1883). EAL, CAL, NAP. A species whose distribution in the study area is restricted to the high-altitude ponds and pools of the Eastern and Central Alps, and Northern Apennines (Stoch, 2006a). Other references: Jersabek et al., 2001; Moroni and Bellavere, 2001; Tavernini et al., 2003; Rossetti et al., 2004; Tavernini, 2008; Tavernini et al., 2005, 2009a; Riccardi et al., 2012; Marrone et al., 2017; Belmonte, 2018.

\section{Subfamily PARADIAPTOMINAE Kiefer, 1932}

Metadiaptomus chevreuxi (Guerne and Richard, 1894). SIC. The species is reported for two temporary water bodies on Favignana island, Sicily (Marrone and Naselli-Flores, 2005; Marrone et al., 2020). Other references: Stoch, 2006a; Marrone, 2006; Marrone et al., 2006a, 2006b, 2009, 2017; Belmonte, 2018.

Neolovenula alluaudi (Guerne and Richard, 1890). APU. Within the study area, this species occurs exclusively in Apulian temporary ponds, often co-occurring with other diaptomid species (Alfonso and Belmonte, 2013). Other references: Alfonso et al., 2016; Marrone et al., 2017; Belmonte, 2018.

\section{Subfamily SPEODIAPTOMINAE Borutzky, 1962}

Troglodiaptomus sketi Petkovski, 1978. KAR. This is the only stygobitic species known for the Italian fauna. $T$. sketi inhabits exclusively the phreatic karstic waters of the Dinaric area (Brancelj, 1991) and was reported for the first time for Italy by Stoch (1984) for several caves of the karstic plateau near Trieste and Gorizia, where it is quite common (Stoch, 2006a). A different subspecies (T. sketi postojnae Brancelj, 1987) was described from the Postojna-Planina cave system in Slovenia, and later considered a junior synonym of $T$. sketi by Brancelj (1991). Other references: Brancelj, 2001, 2005; Stoch, 2017; Brancelj et al., 2020.

\section{Species richness and distribution in the zoogeographical provinces}

On average, Italian provinces hosted $6.5 \pm 3.1$ species (mean \pm standard deviation) each (Tab. 1). However, species richness is not evenly distributed, and the highest diversity was observed in provinces belonging to the Mediterranean macroarea, i.e., in APU and SIC, hosting 13 and 11 species, respectively.

Ten diaptomid species were only observed in the Mediterranean macroarea (i.e., APU, SIC, COR, SAR, TYR), and were absent from other macroareas (see text above, and Tab. 2). Other species were limited to the Alpine and the Padanian macroareas (2 species each), or to the Karst Plateau and the Apennines (1 species each).

The nMDS plot (first two axes) of the Italian provinces and neighbouring limnofaunistic regions (Fig. 2a) shows a well-defined clustering based on the factor macroarea. Two distant and well-characterised clusters include the Italian Alpine provinces (on the left side of the plot) versus the Mediterranean biogeographical units (on the right side of the plot). Iberian (IBE) and Maghreb (MAG) limnofaunistic regions grouped together with the provinces here ascribed to the Mediterranean areas, with only TYR slightly isolated. Hellenic (HEL) and Dinaric (DIN) limnofaunistic regions (the latter including the Italian province KAR) were also plotted together and separated from the other provinces and regions. The northern part of the Alps (NAL) was more related to the Central and Western Highlands (respectively CEH and WEH) than to the Italian Alps (EAL, CAL, WAL). Central and Southern Apennines (CAP and SAP) were more similar each other than to the Northern Apennines (NAP). The Padanian (PAD) province was plotted separately from the other areas, although close to the NAP area.

The species characterizing each macroarea were represented as vectors whose length was proportional to Spearman's correlation coefficient between their presence and nMDS axes (Fig. 2b). Two Paradiaptominae and several Diaptominae species (Mixodiaptomus incrassatus, $M$. lilljeborgi, M. kupelwieseri, Arctodiaptomus wierzejskii, A. salinus, Diaptomus cyaneus, Copidodiaptomus numidicus and the genus Hemidiaptomus - with the sole exception of $H$. superbus, found only in PAD) were characteristic of the Mediterranean area. The Alpine region was characterised by Arctodiaptomus alpinus, Acanthodiaptomus denticornis and Mixodiaptomus tatricus, 
although the latter also occurs in NAP. The presence of a species and a subspecies of the genus Eudiaptomus, namely E. intermedius and E. padanus etruscus, was related to the Apennine region, although the latter also occurs in two Mediterranean provinces (TYR and APU).

\section{DISCUSSION}

The diaptomid fauna of the study area is dominated, in terms of species richness, by the genera Eudiaptomus, Mixodiaptomus, Arctodiaptomus, and Hemidiaptomus, whereas the other genera are represented only by one or
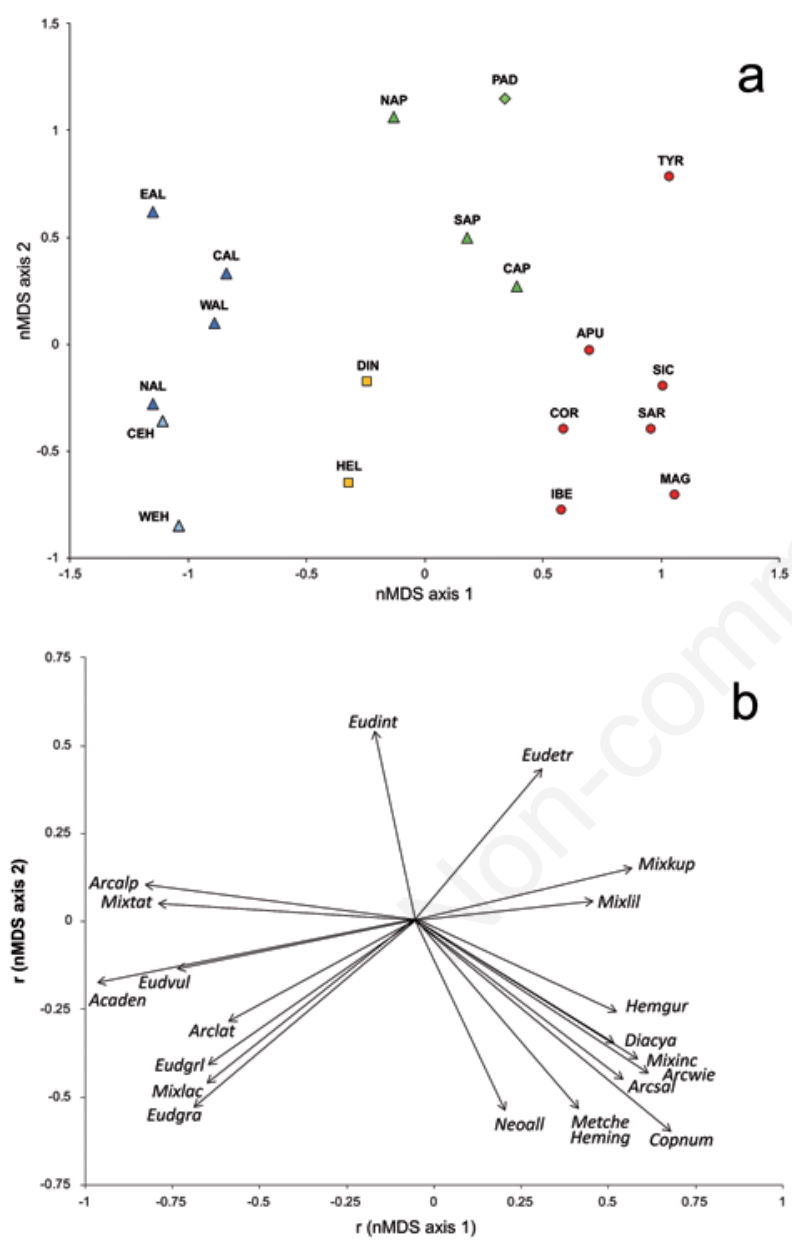

Fig. 2. a) Plot on the plane defined by the first two axes of nMDS ordination of the Italian zoogeographical provinces and neighboring regions based on their diaptomid fauna; groups (different symbols and colours) are defined by the factor 'macroarea' (Tab. 1). b) Plot of the Spearman's correlation coefficients $(p<0.05)$ of the presence of diaptomid species (represented as vectors) with the first two axes of the nMDS ordination. Arclat, Arctodiaptomus laticeps; Eudgrl, Eudiaptomus graciloides; the acronyms of the other species are included in Tab 2. at most two species each. Out of the 30 diaptomid species and subspecies recorded in the study area, two species (Eudiaptomus sp. EMILIA ROMAGNA and Arctodiaptomus sp. SICILY) are new to science and still waiting for a formal description. Moreover, pending a revision of $H$. ingens s.l., the identity of the species ascribed here to Hemidiaptomus cf. inermis remains doubtful, and could be considered as a species close to $H$. ingens (Marrone et al., 2013).

Six species and subspecies, i.e., $20 \%$ of the whole native diaptomid fauna, are endemic or subendemic (sensu Rabitsch and Essl, 2009) to the study area. These are Arctodiaptomus sp. SICILY and Eudiaptomus sp. EMILIAROMAGNA (endemic), and Copidodiaptomus steueri, Eudiaptomus padanus padanus, E. padanus etruscus, and E. intermedius (subendemic).

Most of the species are widespread in the study area (Stoch, 2006a) albeit some taxa are currently known from few or single localities each, and the long-term persistence of their populations should therefore be monitored over time. These are Mixodiaptomus laciniatus, Eudiaptomus sp. EMILIA-ROMAGNA, E. zachariasi, and Hemidiaptomus superbus, which are currently known from a single occurrence locality each, and Metadiaptomus chevreuxi and Hemidiaptomus ingens, which are known from two occurrence localities each.

Eudiaptomus gracilis, the only non-indigenous diaptomid species occurring in the study area, is currently expanding its distribution southwards, and a significant impact on ecologically-similar native Eudiaptomus species is likely, as shown by the evidence collected in northern Italy (Riccardi and Giussani, 2007; Visconti and Manca, 2010).

The species richness observed in the studied provinces ranges from 2 (KAR) to 13 (APU). The low species richness of KAR must be ascribed to the small geographical extension of this province, which is de facto separated from the neighbouring DIN region only by an administrative boundary. The highest species richness was observed in the Mediterranean macroarea, which hosts 19 species and contributes with 10 exclusive occurrences to the diaptomid fauna of the study area. This includes the representatives of the subfamily Paradiaptominae, together with eight Diaptominae species and subspecies (Tab. 2). The high species richness observed in the provinces belonging to the Mediterranean macroarea is probably related to the climatic stability of the area during the Quaternary, which enabled species-rich and ancient diaptomid communities to survive through the Pleistocene climatic fluctuations. This hypothesis is also supported by the distribution of the so-called 'Hemidiaptomus ponds' (Sahuquillo and Miracle, 2013), i.e., temporary ponds hosting rich and unusual crustacean communities characterized by the presence of species of the subgenus Occi- 
dodiaptomus, which are limited to the Mediterranean provinces and are currently considered relics of ancient wetlands (Sahuquillo and Miracle, 2013; Alfonso et al., 2016). Moreover, the presence of a diversified physiography and of complex "pondscapes" including a significant number of temporary water bodies further contributes to the current diaptomid diversity of the Mediterranean provinces. In particular, the high suitability of temporary ponds for diaptomid multi-species coexistence is well known, the most representative case being APU, where the co-occurrence of up to five diaptomids in a single site was reported (Alfonso and Belmonte, 2013; Alfonso et al., 2016). However, most of the non-Mediterranean macroareas, with the sole exception of the Apennines, host species, genera and even subfamilies non found in the other areas (Tabs. 1 and 2).

The similarity among the provinces (and macroareas) are illustrated by the results of the nMDS ordination plot (Fig. 2). The Alpine provinces of the study area (WAL, CAL, and EAL) show a remarkable similarity, whereas the diaptomid fauna of the northern slopes of the Alps is significantly different from these, and closer to Central European faunas (i.e., those occurring in CEH and WEH). This seemingly counterintuitive pattern can be explained by mountain ranges acting as barriers to diaptomid dispersal, as already stressed by Marrone et al. (2017). On the contrary, and in spite of their geographical distance, the affinities between the Mediterranean and neighbouring provinces are evident, thus demonstrating that the sea straits and basins can be easily crossed by diaptomids capable of producing resting eggs. Sea crossing is possible thanks to passive dispersal mediated by biological and physical vectors (Incagnone et al., 2015).

Overall, the diaptomid fauna of the study area is characterized by a high degree of endemism and is well defined with respect to the neighboring areas, thus underlining its significant contribution to the inland water biodiversity of the Western Palearctic and further stressing the role of the Alps as an effective barrier preventing faunal exchanges between southern and northern areas.

In conclusion, although the study area has been investigated for about 150 years, numerous species new to the area or even to Science have been discovered during the last twenty years, suggesting that the diaptomid diversity of the area is still underestimated. We hope this work encourages further investigations to achieve a more comprehensive picture of the diaptomid fauna of the area under consideration.

\section{ACKNOWLEDGEMENTS}

Two anonymous referees are acknowledged for their accurate reviews which allowed to improve a first draft of the manuscript. This work is dedicated to the late prof.
Emilia Stella (1909-1994), who led the research on diaptomids in Italy during the last century.

\section{SUPPLEMENTARY MATERIALS}

File S1 (zip). Shapefile of the Italian zoogeographical provinces.

File S2 (pdf). Matrix of the 55 species distributed in the 19 bioregions considered in the statistical analysis, acronyms and full name of each bioregion.

File S3 (pdf). Scanned copy of a letter sent by prof. Friedrich Kiefer to prof. Emilia Stella on July 17 $7^{\text {th }}, 1973$.

\section{REFERENCES}

Alfonso G, Belmonte G, 2008. Expanding distribution of Boeckella triarticulata (Thomson, 1883) (Copepoda: Calanoida: Centropagidae) in Southern Italy. Aquat. Invasions 3:247-251.

Alfonso G, Belmonte G, Marrone F, Naselli-Flores L, 2010. Does lake age affect zooplankton diversity in Mediterranean lakes and reservoirs? A case study from southern Italy. Hydrobiologia 653:149-164.

Alfonso G, Belmonte G, 2011. Calanoida (Crustacea Copepoda) from the inland waters of Apulia (south-eastern Italy). J. Limnol. 70:57.

Alfonso G, Belmonte G, 2013. Neolovenula alluaudi (Guerne and Richard, 1890) (Calanoida: Diaptomidae: Paradiaptominae): first record in Italy and review of geographical distribution. J. Limnol. 72:e20.

Alfonso G, Beccarisi L, Pieri V, Frassanito A, Belmonte G, 2016. Using crustaceans to identify different pond types. A case study from the Alta Murgia National Park, Apulia (South-eastern Italy). Hydrobiologia 782:53-69.

Anderson MJ, Gorley RN, Clarke KR, 2008. PERMANOVA for PRIMER: guide to software and statistical methods. PRIMER-E, Plymouth.

Angeli N, Cantonati M, Rossetti G, 2002. [Lo zooplancton], p. 135-187. In: M. Cantonati, M. Tolotti amd M. Lazzara (eds.), [I laghi del Parco Naturale Adamello-Brenta]. [Book in Italian]. Parco Naturale Adamello-Brenta, Strembo.

Anufriieva EV, Shadrin N, 2015. Morphometric variability of Arctodiaptomus salinus (Copepoda) in the MediterraneanBlack Sea region. Zool. Res. 36:328-336.

Bagella S, Gascón S, Caria MC, Sala J, Mariani MA, Boix D, 2010. Identifying key environmental factors related to plant and crustacean assemblages in Mediterranean temporary ponds. Biodivers. Conserv. 19:1749-1768.

Bagella S, Gascón S, Caria MC, Sala J, Boix D, 2011. Crosstaxon congruence in Mediterranean temporary wetlands: vascular plants, crustaceans, and coleopterans. Community Ecol. 12:40-50.

Belmonte G, 2018. Calanoida (Crustacea: Copepoda) of the Italian fauna: a review. Eur. Zool. J. 85:273-289.

Belmonte G, Alfonso G, Moscatello S, 2006. Copepod fauna (Calanoida and Cyclopoida) in small ponds of the Pollino 
National Park (South Italy), with notes on seasonality and biometry of species. J. Limnol. 65:107.

Bettinetti R, Garibaldi L, Leoni B, Quadroni S, Galassi S, 2012. Zooplankton as an early warning system of persistent organic pollutants contamination in a deep lake (lake Iseo, Northern Italy). J. Limnol. 71:335-338.

Błędzki, LA, Rybak JI, 2016. Freshwater crustacean zooplankton of Europe. Springer, Cham: 918 pp.

Boix D, Caria MC, Gascón S, Mariani MA, Sala J, Ruhí A, Compte J, Bagella S, 2017. Contrasting intra-annual patterns of six biotic groups with different dispersal mode and ability in Mediterranean temporary ponds. Mar. Freshwater Res. 68:1044-1060.

Bonacina C, Pasteris A, 2001. Zooplankton of Lake Orta after liming: an eleven years study. J. Limnol. 60:101.

Bondavalli C, Bodini A, Rossetti G, Alessina S, 2006. Detecting stress at the whole-ecosystem level: the case of a mountain Lake (lake Santo, Italy). Ecosystems 9:1-56.

Boxshall GA, Defaye D, 2008. Global diversity of copepods (Crustacea: Copepoda) in freshwater. Hydrobiologia 595:195-207.

Brancelj A, 1991. Stygobitic Calanoida (Crustacea: Copepoda) from Yugoslavia with the description of a new species - Stygodiaptomus petkovskii from Bosnia and Hercegovina. Stygologia 6:165-176.

Brancelj A, 2001. Male of Moraria radovnae Brancelj, 1988 (Copepoda: Crustacea), and notes on endemic and rare copepod species from Slovenia and neighbouring countries. Hydrobiologia 453/454:513-524.

Brancelj A, 2005. Hadodiaptomus dumonti n. gen., n. sp., a new freshwater stygobitic calanoid (Crustacea: Copepoda: Calanoida) from Vietnam (South Asia) and a new member of the subfamily Speodiaptominae Borutzky, 1962. Hydrobiologia 534:57-70.

Brancelj A, Mori N, Treu F, Stoch F, 2020. The groundwater fauna of the Classical Karst: hydrogeological indicators and descriptors. Aquat. Ecol. 54:205-224.

Brian A., 1927. [Copepodi raccolti in alcuni laghi delle Alpi e dell'Appennino e descrizione di nuove forme di Diapto$m u s)$ ].[Article in Italian]. Mem. Soc. Entom. Ital. 6:26-36.

Bruno MC, Maiolini B, Carolli M, Silveri L, 2010. Short timescale impacts of hydropeaking on benthic invertebrates in an Alpine stream (Trentino, Italy). Limnologica 40:281-290.

Burckhardt G., 1900. [Faunistische und Systematische Studien über das Zooplanktonder grösseren Seen der Schweiz und ihre Grenzgebiete)].[Article in German]. Rev. Suisse Zool. 7:353-713.

Burckhardt G, 1914. [Notizen über das Zooplankton südlicher Alpenrandseen)].[Article in German]. Internat. Rev. gesamt. Hydrobiol. Hydrogr. 6:1-30.

Casale A, Grafitti G, Lana E, Marcia P, Molinu A, Mucedda M, Onnis C, Stoch F, 2008. [La Grotta del Bue Marino: cinquanta anni di ricerche biospeleologiche in Sardegna)].[Article in Italian]. Proceedings XX National Congresso of Speleology, Iglesias. Mem. Ist. Ital. Speleol. vol. 21.

Champeau A, 1971. [Originalité du peuplement de Copépodes dans les eaux temporaires de Basse-Provence et de Corse)].[Article in Franch]. Ann. Univ. Provence Science 45:55-80.

Champeau A, Thiéry A, 1990.[ Les crustacés entomostracés des eaux stagnantes de Corse. Importance particulière des espèces monovoltines méditerranées de Copépodes Calanoîdes et d'Anostracés dans le Sud-Est de 1'île)].[Article in French]. Bull. Soc. Zool. France 115:55-75.

Cioglia L, Cottiglia M, Tagliasacchi-Masala ML, Rota B, Atzeni A, 1969. [Osservazioni su un lago artificiale ad usi multipli della Sardegna Meridionale. Il lago di Monti Pranu)].[Article in Italian]. Rend. Sem. Fac. Scienze Univ. Cagliari 39:1-32.

Clarke KR, Gorley RN, 2006. PRIMER v6: user manual/ tutorial. PRIMER-E, Plymouth.

Cotta-Ramusino M, Leoni B, 2001. Observations on plankton of Varese Lake 10 years after the loading diversion. Verh. Int. Ver. Limnol. 27:3641-3643.

de Bernardi R, Giussani G, Mosello R, Origgi I, 1984. Quadro limnologico di cinque piccoli laghi piemontesi (Avigliana, Trana, Candia, Viverone e Sirio). Documenta Ist. Ital. Idrobiol. 5:1-97.

dos Santos-Silva EN, Brandorff GO, Cavalcanti MJ, 2018. Distribution of European and African species of genus Diaptomus (Copepoda: Calanoida: Diaptomidae): a track analysis. Nauplius 26:e2018028.

Dussart BH, 1957. [Le genre Diaptomus (Crustacé Copépode) en France)].[Article in French]. Bull. soc. Zool. Fr. 82:169-180.

Dussart B, 1967. [Les Copépodes des Eaux continentales d'Europe occidentale. I. Calanoides et Harpacticoides)].[Book in Franch]. Boubée and Cie, Paris: 500 pp.

Dussart BH, Defaye D, 2001. Introduction to the Copepoda. (2nd ed.). Guides to the Identification of the Microinvertebrates of the Continental Waters of the World, 16. SPB Academic Publishing: 344 pp.

Dussart B, Defaye D, 2002. World Directory of Crustacea Copepoda of Inland Waters, I. Calaniformes. Backhuys Publisher, Leiden: 276 pp.

Einsle U, 1993. [Crustacea Copepoda. Calanoida und Cyclopoida. Süsswasserfauna Mitteleuropas, 8/4-1)].[Book in German]. G. Fischer Verlag, Jena: 208 pp.

Fadda A, Markovà S, Kotlík P, Luglié A, Padedda B, Buscarinu P, Sechi N, Manca M, 2011. First record of planktonic crustaceans in Sardinian reservoirs. Biologia 66:856-865.

Fadda A, Rawcliffe R, Padedda BM, Lugliè A, Sechi N, Camin F, Ziller L, Manca M, 2014. Spatiotemporal dynamics of C and $\mathrm{N}$ isotopic signature of zooplankton: a seasonal study on a man-made lake in the Mediterranean region. Ann. Limnol. - Int. J. Lim. 50:279-287.

Fadda A, Palmas F, Camin F, Ziller L, Padedda BM, Luglié A, Manca M, Sabatini A, 2016. Analysis of $\boldsymbol{\delta}^{13} \mathrm{C}$ and $\boldsymbol{\delta}^{15} \mathrm{~N}$ isotopic signatures to shed light on the hydrological cycle's influence on the trophic behaviour of fish in a Mediterranean reservoir. Biologia 71:1395-1403.

Ferrara O, Vagaggini D, Margaritora FG, 2002. Zooplankton abundance and diversity in Lake Bracciano, Latium, Italy. J. Limnol. 61:169.

Ferrari I, Rossetti G, 2006. New records of the centropagid Boeckella triarticulata (Copepoda: Calanoida) in Northern Italy: evidence of a successful invasion? Aquatic Invasions 1:219-222.

Ferrari I, Benassi G, Cagnolaro L, Parisi G, Rossetti G, Rossi V, Sei S, Viaroli P, 2014. [Un decennio di ricerche idrochimiche e idrobiologiche su laghi e pozze della Val 
d'Aveto (Appennino ligure)].[Article in Italian]. Boll. Mus. Ist. Biol. Univ. Genova 76:36-67.

Fontanella MC, Ravera O, Beone GM, Riccardi N, Cattani I, 2009. Mercury distribution in the main compartments of the eutrophic Lake Candia (Northern Italy). J. Limnol. 68:3528.

Galassi DMP, Fiasca B, Di Lorenzo T, Montanari A, Porfirio S, Fattorini S, 2017. Groundwater biodiversity in a chemoautotrophic cave ecosystem: how geochemistry regulates microcrustacean community structure. Aquat. Ecol. 51:75-90.

Garibaldi L, Anzani A, Marieni A, Leoni B, Mosello R, 2003. Studies on the phytoplankton of the deep subalpine Lake Iseo. J Limnol. 62:177.

Gherardi F, Bertolino S, Bodon M, Casellato S, Cianfanelli S, Ferraguti M, Lori E, Mura G, Nocita A, Riccardi N, Rossetti G, Rota E, Scalera R, Zerunian S, Tricarico, E, 2008. Animal xenodiversity in Italian inland waters: distribution, modes of arrival, and pathways. Biol. Invasions 10:435-454.

Giussani G, de Bernardi R, Mosello R, Origgi I, Ruffoni T, 1986. [Indagine limnologica su i laghi alpini d'alta quota].[Book in Italian]. Documenta Ist. Ital. Idrobiol.: $415 \mathrm{pp}$.

Gurney R, 1909. On the freshwater Crustacea of Algeria and Tunisia. J. R. Micr. Soc. 443:273-305.

Iacobuzio R, Tiberti R, 2011. Cloud cover does not clearly affect the diurnal vertical distribution of crustacean zooplankton in naturally fishless alpine lakes. Plankton Benth. Res. 6:210-214.

Illies J, 1967. [Limnofauna Europaea. Eine Zusammenstellung aller die europäischen Binnengewässer bewohnenden mehrzelligen Tierarten mit Angaben über ihre Verbreitung und Ökologie].[Book in German]. G. Fischer Verlag, Stuttgart: $474 \mathrm{pp}$.

Incagnone G, Marrone F, Barone R, Robba L, Naselli-Flores L, 2015. How do freshwater organisms cross the "dry ocean"? A review on passive dispersal and colonization processes with a special focus on temporary ponds. Hydrobiologia 750:103-123.

Jersabek CD, Brancelj A, Stoch F, Schabetsberger R, 2001. Distribution and ecology of copepods in mountainous regions of the Eastern Alps. Hydrobiologia 453/454:309-324.

Kiefer F, 1954. [Freilebende Ruderfusskrebse (Crustacea Copepoda) aus Binnengewässern Marokkos].[Article in German]. Bull. Soc. Sci. Nat. phys. Maroc 34:317-336.

Kiefer F, 1968. Versuch einer Revision der Gattung Eudiaptomus Kiefer (Copepoda Calanoida). Mem. Ist. Ital. Idrobiol. 24:9-160.

Kiefer F, 1972. Zur Kenntnis von Morphologie und Systematik einiger Arten der Gattung Diaptomus (s. restr.) (Crustacea, Copepoda). Zool. Scr. 1:229-240.

Kiefer F, 1978. [Das Zooplankton der Binnengewaesser. Freilebende Copepoda. Die Binnengewaesser, Band 26 Teil 2].[Book in German]. E. Schweizerbart'sche Verlagbuchhandlung, Stuttgart: $343 \mathrm{pp}$.

Lanfranco S, Cassar LF, 2003. A description of ecological assets in the vicinity of the public waste disposal site at Maghtab, Malta. Malta University Services, Msida.

Langhans V, 1907.[ Faunistische und biologische Studien an der Süsswasser Mikrofauna Istriens].[Article in German]. Lotos (Prague) 6:101-106.

Leoni B, 2017. Zooplankton predators and preys: body size and stable isotope to investigate the pelagic food web in a deep lake (Lake Iseo, Northern Italy). J. Limnol. 76:1490.

Lepori F, 2020. [Breve storia dello zooplancton da crostacei della zona pelagica del Lago di Lugano].[Article in Italian]. Italy Boll. Soc. tic. sci. nat. 108:97-102.

Lepori F, Capelli C, 2020. Seasonal variation in trophic structure and restoration effects in a deep perialpine lake (Lake Lugano, Switzerland and Italy). J. Great Lakes Res. 46:870-880.

Lepori F, Roberts JJ, Schmidt TS, 2018. A paradox of warming in a deep peri-Alpine lake (Lake Lugano, Switzerland and Italy). Hydrobiologia 824:215-228.

Licchelli C, Presta D, Alfonso G, Moscatello S, Belmonte G, 2003. [Prima segnalazione in Italia di Arctodiaptomus kerkyrensis (Crustacea Copepoda Calanoida)].[Article in Italian]. Riv. Idrobiol. 42:1-3.

Losito C, 1901. [Su una nuova specie del gen. Diaptomus Westwood].[Article in Italian]. Boll. Soc. Zool. Ital. 2:150-164.

Magnea U, Sciascia R, Paparella F, Tiberti R, Provenzale A, 2013. A model for high-altitude alpine lake ecosystems and the effect of introduced fish. Ecol. Model. 251:211-220.

Manca M, Armiraglio M, 2002. Zooplankton of 15 lakes in the Southern Central Alps: comparison of recent and past (preca 1850 AD) communities. J. Limnol. 61:225.

Manca M, Cavicchioni N, Morabito G, 2000. First Observations on the effect of a complete, exceptional overturn of Lake Maggiore on plankton and primary productivity. Internat. Rev. Hydrobiol. 85:209-222.

Manca M, Carnovale A, Alemani P, 2004. Exotopic protrusions and ellobiopsid infection in zooplanktonic copepods of a large, deep subalpine lake, Lago Maggiore, in northern Italy. J. Plankton Res. 26:1257-1263.

Marchetto A, Mosello R, Rogora M, Manca M, Boggero A, Morabito G, Musazzi S, Tartari GA, Nocentini Am, Pugnetti A, Bettinetti R, Panzani P, Armiraglio M, Cammarano P, Lami A, 2004. The chemical and biological response of two remote mountain lakes in the Southern Central Alps (Italy) to twenty years of changing physical and chemical climate. J. Limnol. 63:77.

Margaritora FG, Ferrara O, Vagaggini D, 2001. Predatory impact of the mosquitofish (Gambusia holbrooki Girard) on zooplanktonic populations in a pond at Tenuta di Castelporziano (Rome, Central Italy). J. Limnol. 60:189.

Margaritora FG, Bazzanti M, Ferrara O, Mastrantuono L, Seminara M, Vagaggini D, 2003. [Stato attuale delle ricerche bioecologiche sui laghi vulcanici dell'Italia centrale] p. 138-147].[Article in German]. Proceedings International Conference on Residence times in lakes: science, management, education, Bolsena, 2002.

Margaritora FG, Cherubini E, Copetti D, Legnani E, Seminara M, Tartari G, Vagaggini D, 2006. Recent trophic changes in Lake Pusiano (northern Italy) with particular reference to the influence of hydrodynamics on the zooplankton community. Chem. Ecol. 22:S37-S47.

Margraf J, Maas B, 1982. [Zur Ökologie der temporären Süsswasserflachseen des Tafelbergs "Giara di Gesturi" auf Sardinien].[Article in German]. Spixiana 5:69-99.

Marrone F, 2006. The microcrustacean fauna of Sicily and the central Mediterranean Sea area - current knowledge and gaps to be filled. Pol. J. Ecol. 54:681-685.

Marrone F, Naselli-Flores L, 2004. First record and morpholog- 
ical features of Hemidiaptomus (Occidodiaptomus) ingens (Gurney, 1909) (Copepoda Calanoida) in Italy. J. Limnol. 63:250.

Marrone F, Naselli-Flores L, 2005. First record of a representative of the subfamily Paradiaptominae (Copepoda Calanoida Diaptomidae) in Italy: Metadiaptomus chevreuxi (Guerne and Richard, 1894). J. Limnol. 64:89.

Marrone F, Barone R, Naselli-Flores L, 2006a. Ecological characterization and cladocerans, calanoid, copepods and large branchiopods of temporary ponds in a Mediterranean island (Sicily, southern Italy). Chem. Ecol. 22: S181-S190.

Marrone F, Castelli G, Barone R, Naselli-Flores L, 2006b. Ecology and distribution of calanoid copepods in Sicilian inland waters (Italy). Verh Int Ver Limnol. 29:2150-2156.

Marrone F, Castelli G, Naselli-Flores L, 2009. Sicilian temporary ponds: an overview of the composition and affinities of their crustacean biota, p. 189-202. In: I. Fraga and P. Arguimbau (eds.), Proceedings International Conference on Mediterranean Temporary Ponds, Consell Insular de Menorca, Recerca 14.

Marrone F, Lo Brutto S, Arculeo M, 2010. Molecular evidence for the presence of cryptic evolutionary lineages in the freshwater copepod genus Hemidiaptomus G.O. Sars, 1903 (Calanoida, Diaptomidae). Hydrobiologia 644:115-125.

Marrone F, Alfonso G, Miserocchi D, Lo Brutto S, 2011a. First record of Hemidiaptomus (Gigantodiaptomus) superbus (Schmeil, 1895) in Italy, with notes on distribution and conservation status (Copepoda, Calanoida, Diaptomidae). J. Limnol. 70:149.

Marrone F, Stoch F, Galassi DMP, 2011b. Discovery of a stygobiotic population of the epigean diaptomid calanoid Eudiaptomus intermedius (Steuer, 1897) in Central Italy, p. 79. In: Proceedings 11th International Conference on Copepoda, Merida, Mexico.

Marrone F, Lo Brutto S, Hundsdoerfer AK, Arculeo M, 2013. Overlooked cryptic endemism in copepods: systematics and natural history of the calanoid subgenus Occidodiaptomus Borutzky 1991 (Copepoda, Calanoida, Diaptomidae). Mol. Phylogenet. Evol. 66:190-202.

Marrone F, Petrusek A, Alfonso G, Arculeo M, 2014. The diaptomid fauna of Israel (Copepoda, Calanoida, Diaptomidae), with notes on the systematics of Arctodiaptomus similis (Baird, 1859) and Arctodiaptomus irregularis Dimentman and Por, 1985 stat. rev. Zool. Stud. 53:74.

Marrone F, Alonso M, Pieri V, Augugliaro C, Stoch F, 2015. The crustacean fauna of Bayan Onjuul area (Tôv Province, Mongolia) (Crustacea: Branchiopoda, Copepoda, Ostracoda). North-West. J. Zool. 11:288-295.

Marrone F, Havenstein K, Thiedemann R, Ketmaier V., 2016. Identification and characterization of five polymorphic microsatellite loci in the freshwater copepod Hemidiaptomus gurneyi (Copepoda: Calanoida: Diaptomidae). Ital. J. Zool. 83:146-150.

Marrone F, Alfonso G, Naselli-Flores L, Stoch F, 2017. Diversity patterns and biogeography of Diaptomidae (Copepoda, Calanoida) in the Western Palearctic. Hydrobiologia 800:45-60.

Marrone F, Alfonso G, Stoch F, Pieri V, Alonso M, Dretakis M, Naselli-Flores L, 2019. An account on the non-malacostracan crustacean fauna from the inland waters of Crete,
Greece, with the synonymization of Arctodiaptomus piliger Brehm, 1955 with Arctodiaptomus alpinus (Imhof, 1885) (Copepoda: Calanoida). Limnetica 38:167-187.

Marrone F, Ortega F, Mesquita-Joanes F, Guerrero F, 2020. On the occurrence of Metadiaptomus chevreuxi (Calanoida, Diaptomidae, Paradiaptominae) in the Iberian Peninsula, with notes on the ecology and distribution of its European populations. Water 12:1989.

Minelli A, Ruffo S, Vigna Taglianti A, 2006. The Italian faunal provinces. In: S. Ruffo and F. Stoch (eds.), Checklist and distribution of the Italian fauna. Memorie Museo Civico Storia Naturale Verona - serie 2- Sezione Scienze Vita 17:37-39.

Montevago L, Vecchioni L, Marrone F. 2020. First record of Arctodiaptomus wierzejskii (Richard, 1888) (Copepoda Calanoida Diaptomidae) from Malta. Natural History Sciences. Atti Soc. it. Sci. nat. Museo civ. Stor. nat. Milano 7:69-74.

Morabito G, 2017. [C.N.R.-I.S.E. Sede di Verbania. Ricerche sull'evoluzione del Lago Maggiore. Aspetti limnologici. Programma triennale 2016-2018. Campagna 2016].[Book in Italian]. Commissione Internazionale per la protezione delle acque italo-svizzere: $107 \mathrm{pp}$.

Moroni A, Bellavere C, 2001. [Laghi e pozze del versante Nord dell'Appennino settentrionale (Colle di Cadibona - Bocca Serriola) ].[Book in Italian]. CIREA, Dipartimento di Scienze Ambientali, Università di Parma: 367 pp.

Mura G, Brecciaroli B, 2003. The zooplankton crustacean of the temporary waterbodies of the Oasis of Palo (Rome, central Italy). Hydrobiologia 495:93-102.

Naselli-Flores L, Barone R, 2002. Limnology of a small, temporary water body: the Pond of Santa Rosalia (Sicily, Italy). Verh. Internat. Verein. Limnol. 28:1673-1677.

Naselli-Flores L, Marrone F, 2019. Different invasibility of permanent and temporary waterbodies in a semiarid Mediterranean Island. Inland Waters 9:411-421.

Osella G, Pannunzio G, 2013. [Macrobenthos dei laghetti del Gran Sasso d'Italia].[Article in Italian]. Quaderni Museo Storia Naturale Ferrara 1:57-67.

Pesta O, 1938. [Neue Nachweise bemerkenswerter Diaptomiden].[Article in German]. Zool. Anz. 121:150-155.

Pirocchi L, 1942. [Endemotipi di copepodi e cladoceri in piccole acque del Carso].[Article in Italian]. Mem. Ist. ital. Idrobiol. $1: 169-212$.

Pirocchi L, 1947. [Diaptomidi d'alta montagna. III: Il diaptomide di Peirafica (Alpi marittime].[Article in Italian]. Mem. Ist. Ital. Idrobiologia 3:469-476.

Piscia R, Yan ND, Manca MM, 2016. Mechanisms underlying recovery of zooplankton in Lake Orta after liming. J. Limnol. 75:1353.

Piscia R, Boggio E, Bettinetti R, Mazzoni M, Manca M, 2018. Carbon and nitrogen isotopic signatures of zooplankton taxa in five small subalpine lakes along a trophic gradient. Water 10:94.

Rabitsch W, Ess1 F, 2009. [Endemiten - Kostbarkeiten in Österreichs Pflanzen- und Tierwelt].[Book in German] Naturwissenschaft. Ver. Kärnten Umweltbundesamt $\mathrm{GmbH}$, Klagenfurt und Wien: 924 pp.

Ranzoli F, Rottini-Sandrini L, Stolfa D, 1979. [Caratteristiche idrogeochimiche e popolamenti di Copepodi e Cladoceri in tre vaschette di corrosione nel Carso Triestino].[Article in Italian]. Atti Acc. Sci. Bologna Cl Sc. Fis. 6:1-22. 
Ravera O, 1951. [Una nuova forma di Mixodiaptomus kupelwieseri Brehm in Italia].[Article in Italian]. Mem. Ist. Ital. Idrobiol. 6:177-192.

Riccardi N, Giussani G, 2007. The relevance of life-history traits in the establishment of the invader Eudiaptomus gracilis and the extinction of Eudiaptomus padanus in Lake Candia (Northern Italy): evidence for competitive exclusion? Aquat. Ecol. 41:243-254.

Riccardi N, Rossetti G, 2007. Eudiaptomus gracilis in Italy: how, where and why. J. Limnol. 66:64.

Riccardi N, Lucini L, Benagli C, Welker M, Wicht B, Tonolla M, 2012. Potential of matrix-assisted laser desorption/ionization time-of-flight mass spectrometry (MALDI-TOF MS) for the identification of freshwater zooplankton: a pilot study with three Eudiaptomus (Copepoda: Diaptomidae) species. J. Plankton Res. 34:484-492.

Richard J, 1894-1895. [Contribution à l'étude de la faune des Entomostracés de la France].[Article in French]. Feuilles des Jeunes Naturalistes 25:81-84 and 103-108.

Rogora M, Frate L, Carranza ML, Freppaz M, Stanisci A, Bertani I, Bottarin R, Brambilla A, Canullo R, Carbognani M, Cerrato C, Chelli S, Cremonese E, Cutini M, Di Musciano M, Erschbamer B, Godone D, Iocchi M, Isabellon M, Magnani A, Mazzola L, Morra di Cella U, Pauli H, Petey M, Petriccione B, Porro F, Psenner R, Rossetti G, Scotti A, Sommaruga R, Tappeiner U, Theurillat JP, Tomaselli M, Viglietti D, Viterbi R, Vittoz P, Winkler M, Matteucci G, 2018. Assessment of climate change effects on mountain ecosystems through a cross-site analysis in the Alps and Apennines. Sci. Total Environ. 624:1429-1442.

Rossetti G, 2005. Fungal parasitism in freshwater calanoid population: ecological consequences and possible mechanisms involved in the infection process. Hydrobiologia 548:167-176.

Rossetti G, Fratta E, Tireni F, Viglioli S, 2002. Impact of a fungal parasite on the reproductive potential of the freshwater calanoid Eudiaptomus intermedius. Verh. Internat. Verein. Limnol. 28:387-391.

Rossetti G, Bartoli M, Ariotti L, Viaroli P, 2003a. [Studio idrobiologico di ambienti acquatici golenali del Parco Fluviale del Po e dell'Orba (Alessandria) ].[Article in Italian]. Biologia Ambientale 17:53-64.

Rossetti G, Tireni F, Viglioli S, Ferrari I, 2003b. Ricerche ecologiche in un ambiente acquatico della golena del Po nei pressi di Casalmaggiore. Studi Trent. Sci. Nat., Acta Biol. 80:193-200.

Rossetti G, Tireni F, Tavernini S, 2004. Occurrence and ecological characteristics of Mixodiaptomus kupelwieseri (Brehm, 1907) (Copepoda, Calanoida) in mountain water bodies of the northern Apennines, Italy. Ital. J. Zool. 71:123-129.

Rossetti G, Bartoli A, Landi S, Ferrari I, Tavernini S, 2006. Evolution of the zooplankton community in a mountain lake in the last fifty years. Verh. Internat. Verein. Limnol. 29:22092216.

Rossetti G, Viaroli P, Ferrari I, 2009. Role of abiotic and biotic factors in structuring the metazoan plankton community in a lowland river. River Res. Appl. 25:814-835.

Sahuquillo M, Miracle MR, 2013. The role of historic and climatic factors in the distribution of crustacean communities in Iberian Mediterranean ponds. Freshwater Biol. 58:12511266.
Schachter D, Champeau A, 1969. [Contribution à l'étude écologique de la Corse. I. Les Copépodes des eaux stagnantes].[Article in French]. Vie Milieu 20:41-56.

Scirocco T, Ventrella P, Cilenti L, Specchiulli A, Florio M, Breber P, 2008. [Contributo alla conoscenza dell'idrofauna invertebrata e degli anfibi delle acque temporanee del Parco Nazionale del Gargano].[Article in Italian]. Atti. Soc. it. Nat. Museo civ. Stor. Nat. Milano 149:17-23.

Seminara M, Vagaggini D, Margaritora FG, 2008. Differential responses of zooplankton assemblages to environmental variation in temporary and permanent ponds. Aquat. Ecol. 42:129-140.

Seminara M, Vagaggini D, Stoch F, 2015. Long-term monitoring of astatic water bodies: microcrustaceans as indicators of hydroperiod length in ponds and pools. Rend. Fis. Acc. Lincei 26:S345-S352.

Seminara M, Vagaggini D, Stoch F, 2016. A comparison of Cladocera and Copepoda as indicators of hydroperiod length in Mediterranean ponds. Hydrobiologia 782:71-80.

Setubal RB, Riccardi N, 2020. Long-term effects of fish biomanipulation and macrophyte management on zooplankton functional diversity and production in a temperate shallow lake. Limnology 21:305-317.

Stefani F, Leoni B, Marieni A, Garibaldi L, 2010. A new record of Craspedacusta sowerbii, Lankester 1880 (Cnidaria, Limnomedusae) in Northern Italy. J. Limnol. 69:189.

Stella E, 1957. [Il plancton delle acque di una grotta di Sardegna].[Article in Italian]. Boll. Zool. 24:39-44.

Stella E, 1979a. [Considerazioni biogeografiche sui diaptomidi (Copepoda Calanoida) delle acque dolci italiane].[Article in Italian]. Lavori Soc. Ital. Biogeogr. N.S. 6:315-328.

Stella E, 1979b. [Nuovi reperti di Calanidi (Crustacea, Copepoda) in Italia].[Article in Italian]. Mem. Mus. Civ. St. Nat. Verona 6:333-346.

Stella E, 1982. [Guide per il riconoscimento delle specie animali delle acque interne italiane. 14. Calanoidi (Crustacea, Copepoda, Calanoida)].[Book in Italian]. Consiglio Nazionale delle Ricerche AQ/1/140,67 pp.

Stella E, 1984. [Copepoda: Calanoida].[Book in Italian]. Calderini, Bologna: $101 \mathrm{pp}$.

Stella E, 1995. [Calanoida p.p. (specie delle acque interne)]. In: Argano et al. [Crustacea Maxillopoda, Pentastomida. Checklist delle Specie della Fauna italiana].[Book in Italian]. Calderini, Bologna: 28: generi 065-074.

Stoch F, 1984. [Sulla presenza di Troglodiaptomus sketi Petkovski, 1978 (Copepoda, Calanoida) in una grotta del Carso triestino (Italia nordorientale)].[Article in Italian]. Atti e Memorie della Commissione Grotte "E. Boegan" 23:65-67.

Stoch F, 2006a. Crustacea Copepoda Calanoida. In: Ruffo, S. and Stoch, F. (eds), Checklist and distribution of the Italian fauna. Memorie Museo Civico Storia Naturale Verona Serie 2 - Sezione Scienze della Vita 17:91-92.

Stoch F, 2006b. [L'assetto zoogeografico dell'Appennino centro-settentrionale].[Article in Italian]. Biogeographia 27:129-150.

Stoch F, 2017. [Il Lacus Timavi: la fauna acquatica sotterranea, con particolare riguardo alle risorgive del Fiume Timavo].[Article in Italian]. Atti e Memorie della Commissione Grotte "E. Boegan" 47:173-203.

Tanentzap AJ, Morabito G, Volta P, Rogora M, Yan ND, Manca 
M, 2020. Climate warming restructures an aquatic food web over 28 years. Global Change Biol. 26:6852-6866.

Tavernini S, 2008. Seasonal and inter-annual zooplankton dynamics in temporary pools with different hydroperiods. Limnologica 38:63-75.

Tavernini S, Rossetti G, 2001. Lo zooplancton di laghi e pozze dell'appennino Ligure-Emiliano (Val d'Aveto, Val Trebbia, Val Nure, Val d'Arda e Val Taro). Studi Trentini di Scienze naturali - Acta Biologica 78:139-148.

Tavernini S, Fratta E, Sartore F, Rossetti G, 2003. Distribution and ecology of calanoid species in relation to morphometric and chemical characteristics of lakes and ponds of the Northern Apennines, Italy. J. Limnol. 62:28.

Tavernini S, Mura G, Rossetti G, 2005. Factors influencing the seasonal phenology and composition of zooplankton communities in mountain temporary pools. Intern. Rev. Hydrobiol. 90:358-375.

Tavernini S, Primicerio R, Rossetti G, 2009a. Zooplankton assembly in mountain lentic waters is primarily driven by local processes. Acta Oecologica 35:22-31.

Tavernini S, Viaroli P, Rossetti G, 2009b. Zooplankton community structure and inter-annual dynamics in two sand-pit lakes with different dredging impact. Intern. Rev. Hydrobiol 94:290-307.

Ternjej I, Stanković I, 2007. Checklist of fresh and brackish water free-living copepods (Crustacea: Calanoida and Cyclopoida) from Croatia. Zootaxa 1585:45-57.

Tiberti R, 2011. Morphology and ecology of Daphnia middendorffiana, Fischer 1851 (Crustacea, Daphniidae) from four new populations in the Alps. J. Limnol. 70:239.

Tiberti R, Barbieri M, 2011. Evidences of zooplankton vertical migration in stocked and never-stocked alpine lakes in Gran Paradiso National Park (Italy). Oceanol. Hydrobiol. St. 40:36-42.

Tiberti R, Iacobuzio R, 2013. Does the fish presence influence the diurnal vertical distribution of zooplankton in high transparency lakes? Hydrobiologia 709:27-39.

Tiberti R, Metta S, Austoni M, Callieri C, Morabito G, Marchetto A, Rogora M, Tartari GA, Von Hardenberg J, Provenzale A, 2013. Ecological dynamics of two remote Alpine lakes during ice-free season. J. Limnol. 72:e33.

Tiberti R, Brighenti S, Iacobuzio R, Pasquini G, Rolla M, 2014a. Behind the impact of the introduced trout in high altitude lakes: adult, not juvenile fish are responsible of the selective predation on crustacean zooplankton. J. Limnol. 73:969.

Tiberti R, von Hardenberg A, Bogliani G, 2014b. Ecological impact of introduced fish in high altitude lakes: a case of study from the European Alps. Hydrobiologia 724:1-19.

Tiberti R, Brighenti S, Canedoli C, Iacobuzio R, Pasquini G, Rolla M, 2016. The diet of introduced brook trout (Salveli- nus fontinalis; Mitchill, 1814) in an alpine area and a literature review on its feeding ecology. J. Limnol. 75:1366.

Tiberti R, Bogliani G, Brighenti S, Iacobuzio R, Liautaud K, Rolla M, von Hardenberg A, Bassano B, 2019. Recovery of high mountain Alpine lakes after the eradication of introduced brook trout Salvelinus fontinalis using non-chemical methods. Biol. Invasions 21:875-894.

Tiberti R, Buscaglia F, Armodi M, Callieri C, Ribelli F, Rogora M, Tartari G, Bocca M, 2020a. Mountain lakes of Mont Avic Natural Park: ecological features and conservation issues. J. Limnol. 79:1923.

Tiberti R, Buscaglia F, Callieri C, Rogora M, Tartari G, Sommaruga R, 2020b. Food web complexity of high mountain lakes is largely affected by glacial retreat. Ecosystems 23:1093-1106.

Tolotti M, Manca M, Angeli N, Morabito G, Thaler B, Rott E, Stuchlik E, 2006. Phytoplankton and zooplankton associations in a set of Alpine high altitude lakes: geographic distribution and ecology. Hydrobiologia 562:99-122.

Tonolli L, 1959. Eudiaptomus zachariasi Poppe in un laghetto della Conca dei Pantani (Monti Sibillini, Appennino Centrale). Mem. Ist. ital. Idrobiol. 11:61-71.

Troia A, Adragna F, Campisi P, Campo G, Dia MG, Ilardi V, La Mantia T, La Rosa A, Lo Valvo M, Muscarella C, Pasta S, Pieri V, Scuderi L, Sparacio I, Stoch F, Marrone F, 2016. I Pantani di Anguillara (Calatafimi Segesta, Trapani): dati preliminari sulla biodiversità a supporto della tutela del biotopo. Naturalista Siciliano 40:171-200.

Vagaggini D, Ulisse G, Seminara M, Margaritora FG, 2002. Zooplankton communities in two astatic basins in the Natural Reserve of Castelporziano (Central Italy): composition and temporal succession. J. Freshwater Ecol. 17:27-36.

Vecchioni L, Marrone F, Naselli-Flores L, 2019. On the occurrence and distribution of Calanipeda aquaedulcis Kritschagin, 1873 (Copepoda, Calanoida, Pseudodiaptomidae) in Sicily, Italy, with some notes on coexistence and species replacement in calanoid copepods. Adv. Oceanogr. Limnol.10:8177.

Vecchioni L, Sala J, Arculeo M, Marrone F, 2020. On the occurrence of Eudiaptomus gracilis (G.O. Sars, 1863) (Copepoda: Diaptomidae) in Madeira (Portugal). Limnetica 39:571-578.

Viaroli P, Ferrari I, Rossetti G, 2002. Long term limnological research in a quarry lake of the Po River, Italy. Verh. Internat. Verein. Limnol. 28:576-581.

Visconti A, Manca M, 2010. The invasive appearance of Eudiaptomus gracilis (G.O. Sars 1863) in Lago Maggiore. J. Limnol. 69:353.

Visconti A, Manca M, 2011. Seasonal changes in the $\delta^{13} \mathrm{C}$ and $\delta^{15} \mathrm{~N}$ signatures of the Lago Maggiore pelagic food web. J. Limnol. 70:263. 